\title{
Design and Development of Animal Recognition Application Using Gamification and Sattolo Shuffle Algorithm on Android Platform
}

\author{
Case Study: Kebun Binatang Ragunan \\ Samuel Christopher Santo ${ }^{1}$, Ni Made Satvika Iswari ${ }^{2}$ \\ Faculty of Information Technology, Dept. of Computer Science \\ Universitas Multimedia Nusantara, Tangerang, Indonesia \\ samuel.christopher.santo@gmail.com ${ }^{1}$, satvika@umn.ac.id ${ }^{2}$
}

Accepted on May $16^{\text {th }}, 2017$

Approved on June $18^{\text {th }}, 2017$

\begin{abstract}
Information and communication technology has been developed rapidly and affected various aspects such as propagation of information and marketing strategy of tourist attraction. Kebun Binatang Ragunan is one of tourist attraction in Indonesia. Aside from recreation area, Kebun Binatang Ragunan can be a place to learn animals. However, learning animals itself tends to be less attractive and less interactive. Therefore, an application was developed as one of animal learning media to increase tourist motivation. The application developed in form of quiz game by using gamification like achievement to increase their motivation in animals learning and using Sattolo Shuffle algorithm in order to make quiz more varied. After testing, the application is known affect the Behavioral Intention to Use level around $76.96 \%$ and Immersion level around $82.43 \%$ in giving motivation and attracting tourist attention to use the application. Sattolo Shuffle algorithm successfully applied in application to produce a unique sequence of each randomized quiz.
\end{abstract}

Keywords-Achievement, Animal Recognition, Gamification, Quiz Game, Sattolo Shuffle.

\section{INTRODUCTION}

Information and communication technologies have an important role in propagating informations and modification in business strategies of tourism industry [1]. Tourism is an activities for recreation purpose, personal development, or to learn about uniqueness of tourist attraction that visited within a certain period [2]. One of the tourist attraction in Indonesia is Kebun Binatang, located in South Jakarta.

Gamification is one of the example of method that can attract users to have a different experience when visiting a tourist attraction [3]. Gamification is the use of game mechanisms and elements into non-game contexts [4]. Example of elements in gamification such as challenges, points, leaderboard, levels, badges, onboarding, and social engagement loops. Based of research that conducted by [5], the use of gamification in tourism can attract tourist when visiting an attraction, as well as improve experience and motivation in looking for informations at the tourist attraction.

Sattolo Shuffle algorithm is an algorithm for generating a randomized cyclic permutation that can give an unique result of randomness [6]. This algorithm is a modification from Fisher-Yates Shuffle algorithm.

In this research, an animal recognition quiz application with gamification methods and Sattolo Shuffle algorihm on Android platform to increase visitor's motivation to access informations about animals in Kebun Binatang Ragunan.

\section{A. Gamification}

Gamification as a concept has some meaning from some experts as follows.

1. Gamification is the use of game design elements from game into a non-game context [4].

2. Gamification is the application of game-thinking and game mechanisms of the game to engage users in solving daily problems [7].

3. Gamification is the use of game mechanisms, aesthetic values, and thinking patterns to motivate action, learning, and problem solving on people who participate in it [8].

4. Gamification is a process combining something that already exist with game mechanisms that can 
motivate users in taking actions that can yield result to a business [9].

Based on some of these meaning, we can draw conclusion that gamification is a use of game models, mechanisms, elements, and thinking patterns into non-game context in order to motivate users to perform actions such as learning and problem solving. Some of the gamification features according to [7] are points, levels, leaderboards, badges, onboarding (tutorial), challenges, and social engagement loops.

\section{B. Sattolo Shuffle Algorithm}

According [10], Sattolo Shuffle algorithm is an algorithm for generating a randomized cyclic permutation from finite sequence. This algorithm is the result of modification of Fisher-Yates Shuffle, which generate non-biased permutation, like Sattolo Shuffle. Sattolo shuffle has several advantages such as simple concept and randomization of a permutation performed in same array so it can save the use of resources. The steps of Sattolo Shuffle algorithm are summarized from the study of [6] and [10] as follows.

1. Specify the length of the array which will be randomized.

2. Take the length of array into variable $i$.

3. Select a random number $r$ between 0 and (i-1). This number will be array's index pointer.

4. Swap the array element of $r$ with array element of (i-1).

5. Reduce the variable $i$ by 1 and check whether $i$ is greater than 1 . If correct, repeat the third step until the variable $i$ is equal to 1 .

\section{Hedonic-Motivation System Adoption Model}

Hedonic-Motivation System Adoption Model (HMSAM) is a measurement model of a system that adapts from Hedonic-Motivation System (HMS). HMS is a system used to fulfillment intrinsic elements of users motivation based on hedonic characteristic [11]. There are five HMSAM measurement factors: Perceived Usefulness (to measure the performance of a system), Perceived Ease of Use (to measure the ease of use of system usage), Curiosity (to measure of cognitive level in curiosity), Control (perception as if users directly interact with system) and Joy (pleasure gained from interaction between users and system) that may affect Behavioral Intention to Use and Immersion of an application.

\section{Usability Measurement}

According to [12], usability is derived from usable which means it can be used well. [12] also reveals several notions of usability as follows.

- According to [13], usability is a branch of Human Computer Interaction that learn how to design interface in an information system application for convenient use by users

- According to [14], something that can be said to be useful if errors can be eliminated or minimized and gives benefit and satisfaction to the users.

- According to [15], usability refers to how users can learn and use the product to obtain their goals and how satisfied they are with the product

- According to [16], usability is the extent of a product can be used by users to achieve a target that set by effectiveness, efficiency, and satisfaction of product usage in a context such as product usage, tasks, and equipments.

Based on these definition, usability can be measured based on several components:

- Learnability defined how fast users adept in using the system as well as the ease of use of using a system function and what the users want.

- Efficiency defined as the resources spent in order to achieve accuracy and objective.

- Memorability defined how the user's ability to retain knowledge after a certain period, the ability to remember the menu layout always fixed.

- Errors is defined what mistakes that user make, including incompability of what user think with what actually represented by system.

- Satisfaction is defined as freedom from inconvenience, and a positive attitide towards the product usage as the user feels about the system.

\section{E. Qualitative Research Methods, Survey, Likert} Scale

Based on [17] research, qualitative research methods can be interpreted as a form of method that based on postpositivism or interpretive philosophy, that used to examine natural objects with qualitative research results emphasize more in meaning. [17] also stated that qualitative research methods suitable for random sampling data, collecting data based on research instruments, as well as statistical data analysis for hypothesis testing that has been established.

Survey, according to [18] is one of research method that examines large and small population and examines samples drawn from a population to find relative, distributive, and linked events between sociological variables and psychological variables.

Likert scale is a method that can be used to interpret qualitative result into statistical data. Data analysis with qualitative research method is statistical. Therefore, Likert scale is suitable for use along with qualitative research methods that process qualitative data into statistical data to ease in draw conclusions 
[19]. Likert scale has a set of choice that contain statements that represent a value. The Likert scale set must be symmetric and balanced with range of choice from negative to positive choice [20], along with certain score that generate certain values in case be used for data processing [21].

\section{MEthodology}

\section{A. Application Design}

The focus of this research is to make an application contains questions of animal information in Kebun Binatang Ragunan. This application name is Ragunan Zoo Quiz which is built based on Android with Ice Cream Sandwich OS as minimum OS .

Ragunan Zoo Quiz created based on the following gamification elements.

- Challenges are used in form of quiz. The quiz based from information of animals that written on the information board in each of animal cage.

- Onboarding are used in form of tutorials that explain how to use the application from the beginning.

- Levels are used in form of division of Kebun Binatang Ragunan by five areas. The division of areas based on the number of animal species found in each area. Total samples of animal species taken as many as 50 samples with 12 species in Area 1,11 species in Area 2,10 species in Area 3, 4 species in Area 4, and 13 species in Area 5.

- Achievements using Google Play Games Achievement with 17 achievements. Beside achievement, there are also experience point that can be obtained after opening an achievement. Experience point based on quiz area.

TABLE I. ACHIEVEMENTS AND EXPERIENCE POINTS

\begin{tabular}{|l|c|}
\hline \multicolumn{1}{|c|}{ Achievement Name } & $\begin{array}{c}\text { Experience } \\
\text { Points }\end{array}$ \\
\hline $\begin{array}{l}\text { First Time Using } \\
\text { Ragunan Zoo Quiz }\end{array}$ & 1000 \\
\hline First Time Game Over & 500 \\
\hline First Time in Area 1 & 1500 \\
\hline First Time in Area 2 & 1500 \\
\hline First Time in Area 3 & 100 \\
\hline First Time in Area 4 & 500 \\
\hline First Time in Area 5 & 2000 \\
\hline Complete the Area 1 & 2000 \\
\hline Complete the Area 2 & 2000 \\
\hline Complete the Area 3 & 1500 \\
\hline Complete the Area 4 & 1000 \\
\hline
\end{tabular}

\begin{tabular}{|l|c|}
\hline \multicolumn{1}{|c|}{ Achievement Name } & $\begin{array}{c}\text { Experience } \\
\text { Points }\end{array}$ \\
\hline Complete the Area 5 & 3000 \\
\hline Master of Area 1 & 3000 \\
\hline Master of Area 2 & 3000 \\
\hline Master of Area 3 & 2000 \\
\hline Master of Area 4 & 1500 \\
\hline Master of Area 5 & 5000 \\
\hline
\end{tabular}

The more types of animals in one area, the greater the experience point gained.

- Points are used to calculate the correct or wrong answers and the Chance number they have. The result will be used to open the achievement.

- Leaderboard using Google Play Games Leaderboard to show points that users get after completing the quiz.

- Social engagement loops are used in the form of sharing user's point in Twitter.

\section{B. System Design}

\section{B.1. Data Flow Diagram}

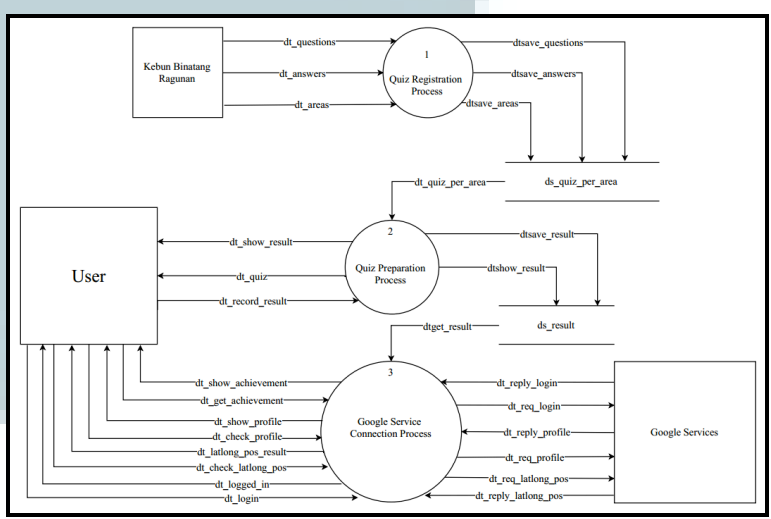

Fig. 1. DFD Level 1

Fig. 1 shows DFD Level 1 of the Ragunan Zoo Quiz system. There are three processes and three entities in the diagram. Three processes include the Quiz Registration Process, Quiz Preparation Process, and Google Service Connection Process. Three existing entities include User, Kebun Binatang Ragunan, and Google Services.

Quiz Registration Process serves to store quiz data and answers on a storage. Quiz Registration Process retrieves data from animal information in Kebun Binatang Ragunan.

Quiz Preparation Process serves to retrieve quiz data and answers and shuffle them to generate a random quiz sequence. The quiz will be displayed to the user and they can solve it. The results in form of a value data will be displayed to user and stored in storage. 
Google Service Connection Process involves Google Service entity. This process authenticates and connects user's account with Google Play Games Service. Once connected to Google Play Games Service, user can view and unlock the achievements in the application. In addition, this process also connect apps with Google Maps Service with intention to showing the user's location on the map.
Preparation process. Calculate Quiz process works to calculate the results obtained from how many wrong or correct answers and chance that user have after do the quiz. Quiz Complete process serves to display the obtained scores.

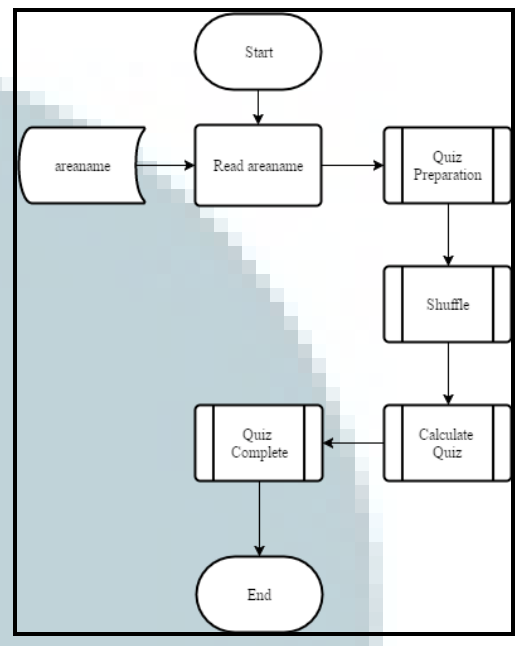

Fig. 3. Flowchart QuizArea

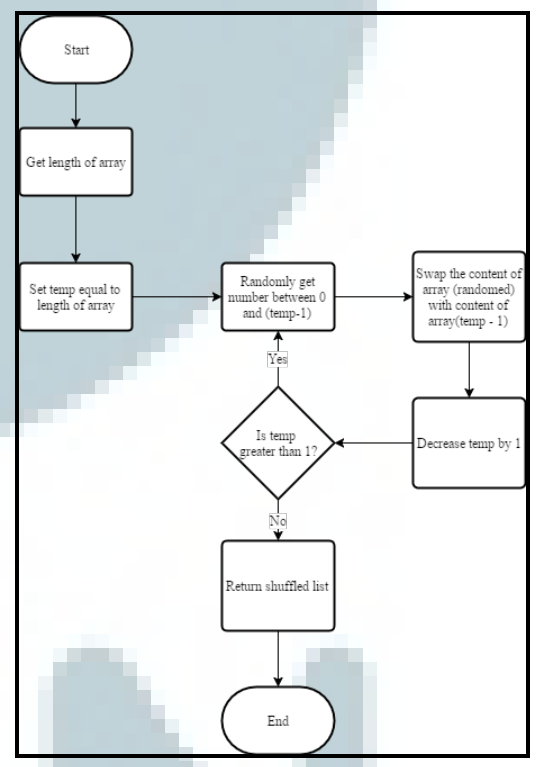

Fig. 4. Flowchart Shuffle

Fig. 4 shows a Shuffle flowchart. After the quiz taken from Quiz Preparation process, Shuffle process will randomize the sequence of the quiz. This process starts by determining the length of the questions' array. Then the length of the questions' stored into the temp variable. After that, a random number is selected between zero and temp minus one, defined as variable $\mathrm{x}$. This selected number will be the index pointer array, defined as variable $r$. After that, swap between content of array $r$ and content of array $x$. The temp variable will be reduced by one and checked whether the temp variable is greater than one. If the temp variable is greater than one, the randomize and 
swapping process will take place until the temp variable is equal to one. If temp variable equal to one, stop the randomization and swapping and return the random results. The randomize result will be used in Calculate Quiz process. Calculate Quiz process will be calculate the result obtained from randomized quiz sequence and calculate the chance user have. The Quiz Complete process serves to display the calculate score from Calculate Quiz process and unlock the achievement based on score, chance, and area.

\section{IMPLEMENTATION, TESTING, EVALUATION}

\section{A. Implementation}

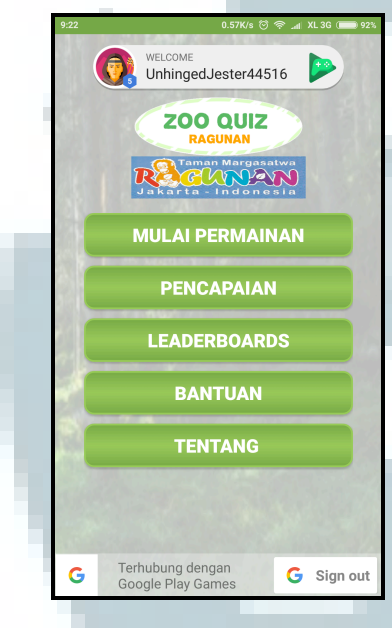

Fig. 5. Tampilan Aplikasi Ragunan Zoo Quiz

The application and system design that have been done will be implemented into the Ragunan Zoo Quiz. Fig, 5 shows the result of Ragunan Zoo Quiz implementation. There are five menus: Mulai Permainan (Game Start) menu to start the quiz, Pencapaian (Achievements) menu to see the list of achievements, Leaderboards menu to see the score per area, Bantuan (Help) menu to see the application usage tutorial, and Tentang (About) menu to see application information.

\section{B. Testing and Evaluation}

After the implementation of Ragunan Zoo Quiz finish, the next step is to test and evaluate the system. Testing were conducted by test the application to the users. From the population of Kebun Binatang Ragunan visitors, sample of participants were taken using accidental sampling. Accidental sampling is a method of determining sample by chance, i.e. anyone who happens to meet with the researcher and considered suitable as a source of data. Total samples taken as many as 37 repondents. The respondents are filling out the questionnaire after doing the application testing. The questionnaire is a set of questions related to Hedonic-Motivation System Adoption Model (HMSAM), usability measurement, and the influence of achievement use on the motivation of participants using Likert scale. The calculation of Likert scale scores with five scales or categories is shown in Table II with ' $\mathrm{X}$ ' as the value obtained.

TABLE II. LIKERT SCALE CATEGORY

\begin{tabular}{|l|c|c|c|}
\hline \multicolumn{1}{|c|}{ Category } & Code & Weight & Category Interpretation \\
\hline $\begin{array}{l}\text { Strongly } \\
\text { Agree }\end{array}$ & $\mathrm{SA}$ & 5 & $X \geq 80 \%$ \\
\hline Agree & $\mathrm{A}$ & 4 & $60 \% \leq X<80 \%$ \\
\hline Neutral & $\mathrm{N}$ & 3 & $40 \% \leq X<60 \%$ \\
\hline Disagree & $\mathrm{D}$ & 2 & $20 \% \leq X<40 \%$ \\
\hline $\begin{array}{l}\text { Strongly } \\
\text { Disagree }\end{array}$ & $\mathrm{SD}$ & 1 & $X<80 \%$ \\
\hline
\end{tabular}

From Table II, a Likert scale formula as follows.

$$
X=\frac{(S A * n S A)+(A * n A)+(N * n N)+(D * n D)+(S D * n S D)}{\text { amount of crieria } * \text { amount of sample }}
$$

Descriptions of (1) are:

- SA is the weight of Strongly Agree equal to 5.

- $\mathrm{nSA}$ is the number of response Strongly Agree category.

- $\mathrm{A}$ is the weight of Agree equal to 4.

- $\mathrm{nA}$ is the number of response Agree category.

- $\mathrm{N}$ is the weight of Neutral equal to 3.

- $\mathrm{nN}$ is the number of response Neutral category.

- $\mathrm{D}$ is the weight of Disagree equal to 2 .

- $\mathrm{nD}$ is the number of response Disagree category.

- $\mathrm{SD}$ is the weight of Strongly Disagree equal to 1.

- $\mathrm{nSD}$ is the number of response Strongly Disagree category.

TABLE III. SUMMARY OF QUESTIONNAIRE

\begin{tabular}{|c|c|c|c|c|c|c|}
\hline$\#$ & $\begin{array}{c}\text { Strongly } \\
\text { Disagree }\end{array}$ & $\begin{array}{c}\text { Dis- } \\
\text { agree }\end{array}$ & $\begin{array}{c}\text { Neu- } \\
\text { tral }\end{array}$ & Agree & $\begin{array}{c}\text { Strongly } \\
\text { Agree }\end{array}$ & Aspect \\
\hline 1 & 0 & 0 & 1 & 23 & 13 & $\begin{array}{c}\text { Perceived } \\
\text { Ease of Use }\end{array}$ \\
\hline 2 & 0 & 0 & 13 & 23 & 1 & $\begin{array}{c}\text { Perceived } \\
\text { Usefulness }\end{array}$ \\
\hline 3 & 0 & 1 & 7 & 20 & 9 & Curiosity \\
\hline 4 & 0 & 0 & 4 & 24 & 9 & Control \\
\hline 5 & 0 & 0 & 10 & 22 & 5 & Joy \\
\hline 6 & 0 & 0 & 6 & 25 & 6 & Immersion \\
\hline 7 & 0 & 9 & 16 & 10 & 2 & $\begin{array}{c}\text { Behavioral } \\
\text { Intentionto } \\
\text { Use }\end{array}$ \\
\hline 8 & 0 & 0 & 2 & 28 & 7 & Learnability \\
\hline 9 & 0 & 0 & 4 & 24 & 9 & Efficiency \\
\hline 10 & 0 & 1 & 10 & 20 & 6 & Satisfaction \\
\hline 11 & 0 & 0 & 5 & 26 & 6 & Motivation \\
\hline
\end{tabular}


Based on Table III, Likert scale is calculated to represent the aspects of HMSAM.

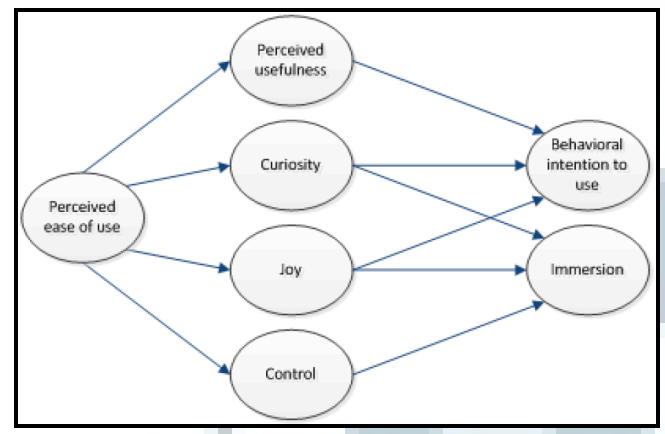

Fig. 6. Hedonic-Motivation System Adoption Model

Based on Fig. 6, there are five HMSAM measurement factors that affect the Behavioral Intention to Use aspect and Immersion aspect. According to Fig. 6 obtained formulas such as:

$$
\begin{gathered}
B I U=\frac{P U+C U+J}{n \text { of aspect }} \\
I=\frac{C U+J+C o}{n \text { of aspect }}
\end{gathered}
$$

Descriptions of (2) and (3) are:

- BIU is Behavioral Intention to Use.

- $\mathrm{I}$ is Immersion.

- PU is Perceived Usefulness.

- $\mathrm{Cu}$ is Curosity.

- $\mathrm{J}$ is Joy.

- Co is Control.

HMSAM calculation result are presented in Table IV.

TABLE IV. LIKERT SCALE RESULT OF HMSAM

\begin{tabular}{|c|c|c|}
\hline HMSAM Aspect & $\begin{array}{c}\text { Likert Scale } \\
\text { Result }\end{array}$ & $\begin{array}{c}\text { Percentage and } \\
\text { Likert Scale } \\
\text { Interpretation }\end{array}$ \\
\hline $\begin{array}{c}\text { Perceived Ease of } \\
\text { Use }\end{array}$ & 0.864864865 & $\begin{array}{c}86.49 \% \\
\text { (Strongly Agree) }\end{array}$ \\
\hline $\begin{array}{c}\text { Perceived } \\
\text { Usefulness }\end{array}$ & 0.8 & $\begin{array}{c}80 \% \\
\text { (Strongly Agree) }\end{array}$ \\
\hline Curiosity & 0.832432432 & $\begin{array}{c}83.24 \% \\
\text { (Strongly Agree) }\end{array}$ \\
\hline Control & 0.845945946 & $\begin{array}{c}84.59 \% \\
\text { (Strongly Agree) }\end{array}$ \\
\hline Joy & 0.818918919 & $\begin{array}{c}81.89 \% \\
\text { (Strongly Agree) }\end{array}$ \\
\hline Immersion & 0.824324324 & $\begin{array}{c}82.43 \% \\
\text { (Strongly Agree) }\end{array}$ \\
\hline $\begin{array}{c}\text { Behavioral } \\
\text { Intention to Use }\end{array}$ & 0.769594595 & $\begin{array}{c}76.96 \% \\
\text { (Agree) }\end{array}$ \\
\hline
\end{tabular}

The Behavioral Intention to Use aspect result around $76.96 \%$ dan Immersion aspect result around $82.43 \%$.

Based on Table III, a Likert scale calculation performed and representd usability and influence of achievement in participants' motivation aspect. The calculation result are presented in Table $\mathrm{V}$.

TABLE V. $\begin{gathered}\text { LIKERT SCALE RESULT OF USABILITY AND } \\
\text { MOTIVATION }\end{gathered}$
\begin{tabular}{|c|c|c|}
\hline $\begin{array}{c}\text { Usability and } \\
\text { Motivation } \\
\text { Aspect }\end{array}$ & $\begin{array}{c}\text { Likert Scale } \\
\text { Result }\end{array}$ & $\begin{array}{c}\text { Percentage and } \\
\text { Likert Scale } \\
\text { Interpretation }\end{array}$ \\
\hline Learnability & 0.827027027 & $\begin{array}{c}82.7 \% \\
\text { (Strongly Agree) }\end{array}$ \\
\hline Efficiency & 0.827027027 & $\begin{array}{c}82.7 \% \\
\text { (Strongly Agree) }\end{array}$ \\
\hline Satisfaction & 0.767567568 & $\begin{array}{c}76.76 \% \\
\text { (Agree) }\end{array}$ \\
\hline $\begin{array}{c}\text { Achievement as } \\
\text { Motivation }\end{array}$ & 0.805405405 & $\begin{array}{c}80.54 \% \\
\text { (Strongly Agree) }\end{array}$ \\
\hline
\end{tabular}

Learnability aspect is around $82.7 \%$, Efficiency aspect is around $82.7 \%$, and Satisfaction aspect is around $76.76 \%$. The influence of achiement in participants' motivation is around $80.54 \%$.

Beside the application testing by participants, Sattolo Shuffle algorithm also tested to prove randomness using Sattolo shuffle produce a unique randomization. This testing was conducted on 81 quiz questions with 50 randomization tests. From these 81 quiz questions, the first ten questions were taken to show the uniqueness of randomized sequence.

TABLE VI. SATtolo ShUfFle AlgORIthM TEST

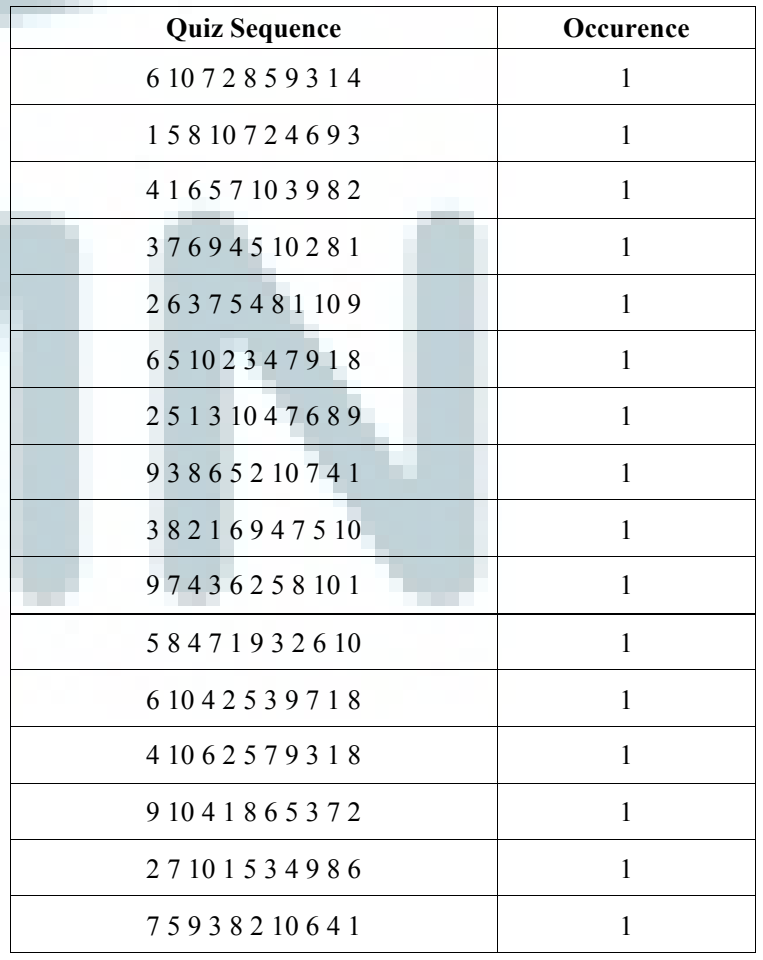


ISSN 2354-0082

\begin{tabular}{|c|c|c|}
\hline Quiz Sequence & Occurence & \multirow{8}{*}{$\begin{array}{l}\text { V. CONCLUSION } \\
\text { 1. Animal recognition quiz application using } \\
\text { gamification method and Sattolo Shuffle } \\
\text { algorithm on Android platform has been } \\
\text { successfully designed and built, named Ragunan } \\
\text { Zoo Quiz. This application already has seven } \\
\text { gamification elements such as points, levels, } \\
\text { leaderboards, achievement and badges, } \\
\text { challenges and quests, onboarding, dan social } \\
\text { engagement loops. }\end{array}$} \\
\hline 38297410561 & 1 & \\
\hline 10387614295 & 1 & \\
\hline 21047359618 & 1 & \\
\hline 21104938765 & 1 & \\
\hline 89372103541 & 1 & \\
\hline 62384719105 & 1 & \\
\hline 82751934106 & 1 & \\
\hline
\end{tabular}

2. Ragunan Zoo Quiz generate Immersion rate around $82.43 \%$ which means users strongly agree that using Ragunan Zoo Quiz can keep them focused using the application and Behavioral Intention to Use rate around $76.96 \%$ which means users agree to use Ragunan Zoo Quiz in the future.

3. Ragunan Zoo Quiz also produces Learnability aspect around $82.7 \%$ which means users strongly agree that Ragunan Zoo Quiz is easy to use and fast to learn, resulting Efficiency around $82.7 \%$ indicating users strongly agree no need excess effort in using application, and Satisfaction around $76.76 \%$ which shows that users agree to the satisfaction gained after using Ragunan Zoo Quiz.

4. The influence of achievement usage to motivate users produced result around $80.54 \%$ indicating users strongly agree that achievement usage affect the users motivation to use Ragunan Zoo Quiz.

5. Sattolo Shuffle algorithm also successfully applied to randomized question and generate an unique sequence. This statement proven by 50 randomization tests and produced 50 unique sequence variations that different from each other.

\section{REFERENCES}

[1] Egger, R. 2012. The impact of near field communication on tourism. In Journal of Hospitality and Tourism Technology, 4(2), p. 119-133.

[2] Undang-Undang Republik Indonesia. 2009. Undang-Undang Republik Indonesia Nomor 10 Tahun 2009 [online]. Available in: http://peraturan.go.id/uu/nomor-10-tahun-2009.html [accessed on 21 March 2016].

[3] World Travel Market. 2011. WTM Global Trends Report 2011. Available in: http://www.toposophy.com/files/1/files/onsite global trends v3 lo.pdf [accessed on 13 April 2016].

[4] Deterding, S., Khaled, R., Nacke, L.E., and Dixon, D. 2011. Gamification: Toward a Definition. CHI 2011 Workshop Gamification: Using Game Design Elements in Non-Game Contexts[online]. Available in: http://gamificationresearch.org/wpcontent/uploads/2011/04/CHI 2011 Gamification Workshop .pdf [accessed on 21 March 2016].

[5] Xu, F., Tian, F., Buhalis, D., Weber, J., and Zhang, H. 2015. Tourist as Mobile Gamers: Gamification for Tourism Marketing. In Journal of Travel and Tourism Marketing.

[6] Sattolo, S. 1986. An Algorithm to Generate a Random Cyclic Permutation. Information Processing Letters, 22(6), p. 315317.

[7] Zichermann, G. and Cunningham, C. 2011. Gamification by Design: Implementing Game Mechanics in Web and Mobile 
Apps.First edition. O'Reilly Media, Inc., Sebastopol, California.

[8] Kapp, K.M. 2012. The Gamification of Learning and instruction: Game-based Methods and Strategies for Training and Education. Pfeiffer, San Fransisco, CA.

[9] Bunchball. 2012. What is Gamification? Available in: http://www.bunchball.com/gamification [accessed on 23 March 2016].

[10] Wilson, M.C. 2004. Overview of Sattolo's Algorithm. New Zealand, Auckland.

[11] Lowry, P.B., Gaskin, J.E., Twyman, N.W., Hammer, B., and Roberts, T.L. 2013. Taking "Fun and Games" Seriously: Proposing the Hedonic-Motivation System Adoption Model (HMSAM). In Journal of the Association for Information System, 14(11), p. 617-671.

[12] Rahadi, D.R. 2014. Pengukuran Usability Sistem Menggunakan Use Questionnaire Pada Aplkasi Android. Jurnal Sistem Informasi (JSI), 6(1), p. 661-671.

[13] Nugroho, E. 2009. Desain Situs Reader Friendly. Andi Offset, Yogyakarta.

[14] Rubin, J. and Chisnell, D. 2008. Handbook of Usability Testing: How to Plan, Design, and Conduct Effective Tests.Wiley Publishing, New Jersey.
[15] Dumas, J.S. and Redish, J.C. 1999. A Practical Guide to Usability Testing. Intellect Books, UK.

[16] International Organization for Standardization. 1998. ISO 9241-11:1998 Ergonomic requirements for office work with visual display terminals (VDTs) -- Part 11: Guidance on usability. Available in: https://www.iso.org/standard/16883.html [accessed on 20 April 2016].

[17] Sugiyono. 2013. Metode Penelitian Manajemen. First edition. Alfabeta, Bandung.

[18] Kerlinger, F.N. 2004. Asas-asas Penelitian Behavioral. Gajah Mada University Press, Yogyakarta.

[19] Trochim, W.M.K. 2006. Likert Scaling. Available in: http://www.socialresearchmethods.net/kb/scallik.php [accessed on 26 March 2016].

[20] Uebersax, J.S. 2006. Likert Scale: Dispelling the Confusion. Available in: http://www.john-uebersax.com/stat/likert.htm [accessed on 26 March 2016].

[21] Likert, R. 1932. A Technique for the Measurement of Attitudes. Archives of Psychology, 22, p. 5-55.
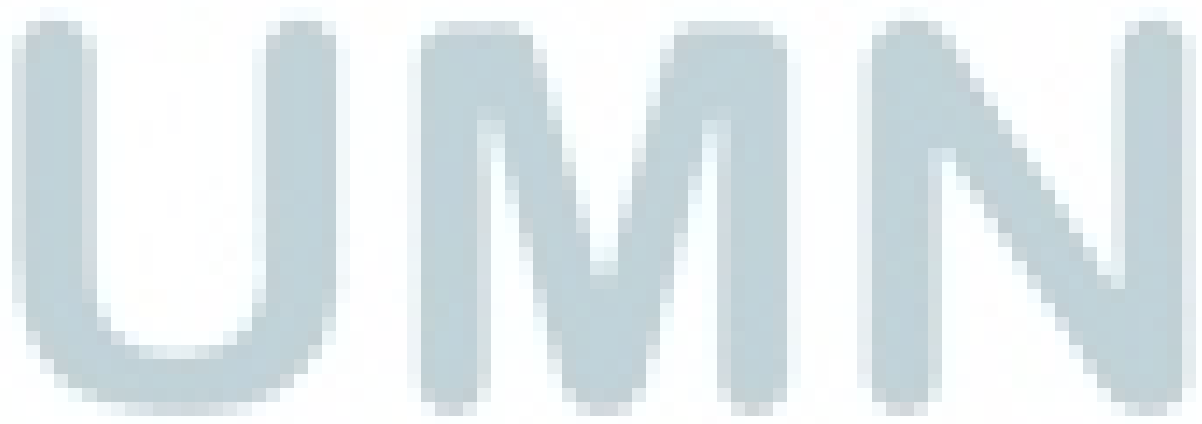